\title{
Career satisfaction of postdoctoral researchers in relation to their expectations for the future
}

\author{
Inge van der Weijden ${ }^{1}$ Christine Teelken ${ }^{2} \cdot$ Moniek de Boer $^{2}$ • \\ Mariske Drost ${ }^{2}$
}

Published online: 1 September 2015

(C) The Author(s) 2015. This article is published with open access at Springerlink.com

\begin{abstract}
While postdoctoral researchers (postdocs) are an increasingly important and productive group of employees in academia, they lack further career prospects and embeddedness within their organizations. This paper provides a rare glimpse into this relatively unexplored but important group. A comparative study of two Dutch universities included a survey with both closed and open questions among 225 respondents. Our study reveals that nearly all postdocs $(85 \%)$ want to stay in the academic field, but only $<3 \%$ was offered a tenure-track position. The uncertainty of their future prospects in academia lowered their job satisfaction; this is particularly true for the social sciences and humanities. Concerning alternative career paths, only few of the postdocs spent time in preparing for a career outside academia, and less than a third attempted to develop any transferable skills, although the importance of networking was recognized. Given that postdocs seem to be trapped between their own ambitions and a lack of academic career opportunities, it is very important that, on the one hand, postdocs aim for better visibility within their organizations, while on the other hand, universities provide more clarity and openness about their further career prospects inside and outside academia.
\end{abstract}

Electronic supplementary material The online version of this article (doi:10.1007/s10734-015-9936-0) contains supplementary material, which is available to authorized users.

Inge van der Weijden

i.c.m.van.der.weijden@cwts.leidenuniv.nl

Christine Teelken

j.c.teelken@vu.nl

Moniek de Boer

moniekdeboer@live.nl

Mariske Drost

Mariskedrost@gmail.com

1 Centre for Science and Technology Studies, Leiden University, Leiden, The Netherlands

2 Department of Organisation Sciences, VU University Amsterdam, Amsterdam, The Netherlands 
Keywords Postdoctoral researchers - Academic careers - Human resource management . Job satisfaction

\section{Introduction}

In academic research, postdoctoral researchers (postdocs) are an increasingly important group. They are highly educated, specialized, and productive professionals (e.g., O'Grady and Beam 2011) who contribute to economic and social growth in European countries (Häyrinen-Alestalo and Peltola 2006) and are responsible for a disproportionate share of discoveries and innovations (Davis 2009). Postdocs are also the source of future productivity because postdoctoral appointments are the platform from which the next generation of researchers embarks on independent research careers (Mitchell et al. 2013). They also have the potential to become key players, bridging knowledge between national and international scientific and scholarly networks (Horta 2009). However, despite the important roles of postdocs in academic enterprises, their academic career trajectories are characterized by invisibility as well as uncertainty, resulting in three interrelated problems. One is our limited knowledge concerning the growing population of postdocs, despite their increasing substance and importance to research and society in the long term. We hardly know who they are demographically or their preliminary careers and postdoc trajectories. A second problem is that postdocs are weakly embedded and not recognized as a separate staff category within universities (Van Balen 2010; Nerad and Cerny 1999). Policies for postdocs concerning talent management and professional development are underdeveloped (Thunnissen and Fruytier 2014; Thunnissen et al. 2013; Mitchell et al. 2013) or lack quality standards (e.g., Felisberti and Sear 2014). The third problem is the uncertainty of postdoc career prospects. Postdocs tend to work on a series of temporary contracts, awaiting promotion to tenured positions, which in the Netherlands averages $20 \%$ per year (e.g., De Goede et al. 2013). Studies in countries such as the USA and Canada report comparable figures (e.g., Editorial 2004; Stanford et al. 2009). More than half of all Ph.Ds leave the higher education sector because of lack of opportunity (McAlpine and Emmioğlu 2014).

Academic careers in European higher education systems have changed substantially over a relatively brief time (Kwiek and Antonowicz 2015; Prpic et al. 2014), although there

Table 1 Summary of empirical studies among postdocs employed in different countries

\begin{tabular}{llllll}
\hline Study & Country & Age (years) & $\begin{array}{l}\text { Female } \\
(\%)\end{array}$ & $\begin{array}{l}\text { International } \\
\text { background } \\
(\%)\end{array}$ & $\begin{array}{l}\text { Average length } \\
\text { of postdoc } \\
\text { position (years) }\end{array}$ \\
\hline Felisberti and Sear (2014) & UK & $26-40$ & 62 & 55 & NR \\
Fitzenberger and Schulze (2013) & Germany & 38 & 34 & NR & 5.6 years \\
Mitchell et al. (2013) & Canada & 34 & 46 & 52 & 3.2 years \\
De Goede et al. (2013) & Netherlands & $30-34$ & 44 & NR & $2-3$ years \\
Scaffidi and Berman (2011) & Australia & NR & 47 & NR & NR \\
Stanford et al. (2009) & Canada & $30-35$ & 44 & NR & 3 years \\
NISTEP (2008, 2009) & Japan & $30-34$ & 25 & NR & 2.7 years \\
\hline
\end{tabular}

$N R$ not reported 
are, of course, differences among countries. Whereas earlier such careers occurred in a quite unstructured manner and on an ad hoc basis, career steps are now segmented into comparable time frames, must be carried out within a limited period, and consist of doctoral systems, postdoctoral positions, or junior functions followed by employment in a lower-level and subsequently a higher-level senior position such as a full professorship. For each segment, a limited time frame and specific output criteria have been formulated, and these criteria are increasingly similar across several countries (Kwiek and Antonowicz 2015). In addition, not only has the time frame changed but also positioning within the organization. Postdocs are not only progressively more common but also are conducting a substantial share of the research (Davis 2009). Studies focusing on academic careers are increasingly available, but only a few (see Table 1 for an overview) deal explicitly with the career prospects of postdocs (e.g., Bessudnov et al. 2014; Davis 2009; De Goede et al. 2013; Felisberti and Sear 2014; Fitzenberger and Schulze 2013; Mitchell et al. 2013; NISTEP 2008, 2009; Scaffidi and Berman 2011; Stanford et al. 2009). The Australian study by Scaffidi and Berman (2011) examined the variables that impact the postdoctoral experience or research productivity to determine whether quality of supervision, career mentoring, collaboration, networking, and a nurturing research environment made positive differences in the experiences and productivity of postdoctoral researchers. They confirmed that job insecurity and a lack of career structure continue to be ongoing concerns for postdocs, but they also revealed a clear link between the quality of supervision and a positive postdoc experience, particularly when supervisors take responsibility for their postdocs' future career prospects. In addition, mentoring in preparation for non-academic careers could be greatly improved. Davis's work (2009), based on a survey of 8500 postdocs in the USA, demonstrated that several straightforward and inexpensive measures such as written research plans, exposure to non-academic careers, and training in teaching skills can result in a great difference in postdoc productivity and the overall quality of their experience. Bessudnov et al. (2014) carried out an evaluation of the Max Weber Postdoctoral Programme and discovered, on the basis of a matching study, that this structured program had a significant positive effect on the general life satisfaction of former fellows as well as on their publication activities. Therefore, an active and collegial research environment may improve the academic outcomes of postdoctoral fellows.

It is generally assumed that those with doctoral degrees have more complex career orientations (Schomburg 2007) and conceptions of career success than other workers. This complexity appears in different ways, as further discussed below.

Several international studies have demonstrated that a postdoc function is no longer a short-term entrance trajectory into the university but more likely a longer-lasting experience, as postdocs tend to work on a series of temporary contracts (Fitzenberger and Schulze 2013; Stanford et al. 2009; NISTEP 2009). A recent study by Bäker (2015) showed that moving to another university has a negative effect on the postdoc's social capital, as moving creates a distance between their former colleagues and co-authors and, thereby, a short-term dip in their research output. A postdoc trajectory can be considered a preliminary requirement for obtaining a permanent position. However, a long wait for a tenured position seems to reduce the opportunities to achieve such a position, as postdocs age and become more specialized (Van Balen 2010). While their knowledge of career opportunities grew, their personal horizons for action became narrower because of changing personal relationships and responsibilities (McAlpine and Emmioğlu 2014). It is particularly this longer duration of insecure career prospects that adds to the dissatisfaction of postdocs in their current work. Therefore, a second complexity can be derived from the ambivalence concerning the postdoc trajectory. Because a growing number of Ph.D. 
students are trained at universities (De Goede et al. 2013), Ph.D. graduates who wish to pursue an academic career end up in fixed-term appointments as postdocs or researchers on an external research grant, and this often involves multiple relocations (McAlpine 2012). Some postdoctoral researchers succeed in finding a potentially or actually tenured position, while others lack clear career prospects and tend to accumulate a number of postdoc positions and eventually leave academia (Van Arensbergen et al. 2013). Piling up postdoc positions within the same research group at the same location has generally a negative influence on the career prospects of researchers (Van Balen 2010). Differences between academic disciplines are clearly relevant, but several studies focused on only one discipline (e.g., Bessudnov et al. 2014) or on one field (e.g., Leonard et al. 2004) or compared two closely related fields of science (e.g., Bäker 2015; Nerad and Cerny 1999).

Postdocs are working within academic institutions in modern-day society. These institutions have changed substantially over recent decades in regard to tasks, structure, and culture because of increased internationalization, less government influence and funding, and a larger impact of external stakeholders (Enders et al. 2011). As a result of an increased focus on entrepreneurialism and competition, universities have extended their traditional objectives such as knowledge development and sharing to the commercialization of knowledge (Zomer and Benneworth 2011). Consequently, universities will have to work more efficiently to become and remain more attractive employers. The ability to attract and retain "top talent" is rapidly becoming a key HRM issue for universities (Van den Brink et al. 2013). In this respect, as emphasized by Bulmahn (2001), it is remarkable that postdocs receive so little attention in the academic landscape. The career development of post-Ph.Ds seems to occur rather coincidentally, as a sort of black box and without the influence of any systematic career planning (Van Arensbergen et al. 2013; McAlpine and Emmioğlu 2014; Davis 2009). Although professional managers and staff have entered universities nowadays, Thunnissen and Fruytier (2014) showed, by analyzing HRM practices in Dutch universities, that scientific staff including professors are still the main actors in the career development of early career scientists. At the same time, most scientists know how to avoid any administrative logistics and sustain their own autonomy and academic freedom (Teelken 2008, 2015).

Concerning their career prospects, most young academics like postdocs pay little attention to the possibility or the necessity of a career beyond academia. They are ambitious and confident about succeeding in an academic career (Fitzenberger and Schulze 2013). Generally, they expect to belong to "the happy few" (Freijsen et al. 2011) who are able to continue their careers in academia. A survey carried out in Quebec by Gemme and Gingras (2012) showed that acquiring a professorship continues to be the single most valued career path for Ph.D. graduates, despite being persuaded to consider alternative, non-academic career paths. The pursuit of an academic career continues to dominate the professional dreams of post-Ph.D. researchers and only increases as they move ahead in their programs. The studies by Van Balen et al. (2012) and Van Arensbergen et al. (2013) both revealed a lack of systematic career policies and the crucial impact of accumulating incidental factors, which eventually resulted in either an academic career or leaving academia.

The aim of this paper is to discuss the position of postdoctoral researchers within academia and within the organization as it relates to their future prospects. The postdoc situation as described in this introduction leads to three research questions:

a. What are the career trajectories, preparations, and prospects of postdocs?

b. What preparations are they making to advance their careers? 
c. How are postdocs' current work environments organized and how satisfied are they with these work environments?

We will examine these research questions by considering gender and nationality differences within postdoc groups.

\section{Materials and methods}

This project explores the working conditions and career expectations of postdocs. Since a uniform definition of the postdoc researcher is currently unavailable, we decided to use the following description: "Postdoctoral researchers (postdocs) are newly qualified researchers with a Ph.D. and/or MD backgrounds, working autonomously in research at universities or related institutions but without a tenured contract" (Stanford et al. 2009, p. 3). The data for this study were collected between May 2013 and March 2014 in a web (Qualtrics) online survey of postdoctoral researchers employed at two universities (one technical university and one general university) located in the Netherlands. We have chosen these universities because they represent the two major categories of traditional, research-oriented universities in the Netherlands and because both employ a substantial number of postdocs. The names and e-mail addresses of postdocs were obtained from each university's HRM department. A total of 225 postdocs completed the questionnaire, resulting in an overall response rate of $39 \%$. Our survey comprised 36 questions (please see supplement I) and focused on job satisfaction, career prospects, and mentorship. Statistical analyses were conducted using SPSS 21.0.0.1.

At four different points in the questionnaire, we asked respondents to elaborate on their answers, which many of them did extensively. The advantages of these open-ended questions include the possibility of discovering the responses that individuals give spontaneously, thus avoiding the bias that may result from suggesting responses to individuals, a bias which may occur in the case of close-ended questions (Reja et al. 2003). We analyzed these answers with the help of open coding and used quotes to provide illustrations and explanations of our findings. The quotes are assigned with the gender, age, nationality, and number of children of the respondent. It is generally known that the amount of missing data, either non-valid responses or skipping of the question, is larger for the open-ended question compared to closed questions. Therefore, it is likely that the respondents who answer the open-ended questions were particularly unhappy about their careers. Consequently, findings of the open questions should be interpreted with extra care.

As postdocs are not considered a separate category of staff at the institutional level, we do not have information about the age, discipline, gender, or nationality of our nonresponse group. Gender and nationality data are available but on a national level only. A comparison of the gender of the respondents and the gender of the total population of postdocs in the Netherlands (44\% are female, according to De Goede et al. 2013) shows that the respondents provide sufficient representation. In 2011, $49 \%$ of the postdocs employed at universities in the Netherlands had a non-Dutch nationality (De Goede et al. 2013). This suggests that there is an overrepresentation of non-Dutch nationals compared to Dutch nationals among the respondents.

A review of the Dutch academic career system shows that postdoctoral researchers are not recognized as a separate group in the national classification system of function, nor did we come across any specific HRM policies concerning this group of employees. They are part of the group "other academic staff," including lecturers and other researchers on 
temporary contracts, but they do not belong to the academic faculty. In 2005, there were 2559 postdocs in the Netherlands; this number increased to 3463 in 2011 (Van Arensbergen et al. 2013). The standard upward career trajectory depends on both the individual merits of an academic and the positions available in the science system. De Goede, Belder and De Jonge (2013) recently estimated that about 750 assistant professorships are available each year, covering only about $20 \%$ of the postdoc population in the Netherlands. This is not very different from the situation in other countries, as De Grande et al. (2010) and Stanford et al. (2009) described that two-thirds of postdocs have to leave academia. In order to support young scientists in both academic and alternative career orientations, the Postdoc Career Development Initiative was established in the Netherlands in 2008. The initiative aims to serve as a mediator between Ph.Ds and academia, industry, public-private partnerships, and others (PCDI 2012). Until now, the scope of this initiative has been rather limited because of its focus to postdocs in the life sciences. HRM development and talent policies at universities in the Netherlands have taken shape mostly through the development of personalized instruments. The most important example is the so-called tenure-track system, involving a clear career path with predetermined achievement criteria and the Innovational Research Incentives Scheme. However, the actual impact of these instruments on the postdoc population as a whole is quite limited, as they serve only a very small group of outstanding researchers (Van Arensbergen et al. 2013).

\section{Results}

\section{Demographics}

In regard to gender, $60 \%(n=134)$ of the respondents are male and $40 \%(n=91)$ female. However, the gender distribution differed between the two universities $\left(\chi^{2}(1\right.$, $N=225)=14.420, p<0.001)$. As shown in Table 2, at the technical university, there is gender inequality ( $26 \%$ females), but at the general university, the ratio is in equilibrium (52\% females; $48 \%$ males). The average age of the postdocs is 34 years, and $34 \%$ have

Table 2 Overview of the demographics

\begin{tabular}{|c|c|c|c|c|}
\hline Respondents & 225 & $\begin{array}{l}\text { Males }=134 \\
(60 \%)\end{array}$ & $\begin{array}{l}\text { Females }=91 \\
(40 \%)\end{array}$ & $\begin{array}{l}\chi^{2}=14.420 \\
p<0.001\end{array}$ \\
\hline $\begin{array}{l}\text { General } \\
\text { university }\end{array}$ & & $48 \%$ & $52 \%$ & \\
\hline $\begin{array}{l}\text { Technical } \\
\text { university }\end{array}$ & & $74 \%$ & $26 \%$ & \\
\hline Average age & 34 years & 33 years & 35 years & $p=0.017$ \\
\hline Children & $34 \%$ & & & \\
\hline Non-Dutch & $65 \%$ & & & \\
\hline Disciplines & $\begin{array}{l}\text { Sciences }=47 \% \\
\text { Technical and } \\
\text { engineering }=24 \% \\
\text { Humanities }=11 \% \\
\text { Social and } \\
\text { behavioral }=9 \% \\
\text { Archeology }=7 \%\end{array}$ & & & \\
\hline
\end{tabular}


children. Their age is comparable with postdocs employed in other countries such as the USA, Japan, and Canada; only German postdocs are older at an average 38 years of age (see Table 1). Our female postdocs are, on average, 2 years older than male postdocs (35 vs. 33 years; $p=0.017$ ). Half of the respondents (47 \%) work in the science faculty (e.g., chemistry, mathematics, computer science, astronomy, physics, biology, environmental science). The remaining postdocs are employed in technical sciences and engineering (24\%), humanities $(11 \%)$, social and behavioral sciences $(9 \%)$, and archeology $(7 \%) .{ }^{1}$ Of particular note is the large number of international postdocs employed at both universities in the Netherlands. In the survey, $65 \%$ of the postdocs who responded had a nonnative nationality compared to $50 \%$ of the postdocs employed in the USA (Cantwell and Taylor 2013). Postdocs with Dutch nationality are older (36 vs. 33 years; $p<0.001$ ) and more experienced (Ph.D. 4.5 vs. Ph.D. 3 years before survey study; $p<0.001$ ), and they more often have children compared to their international colleagues (51 vs. $25 \%$; $p<0.001)$.

\section{Career trajectory of postdocs}

\section{Being a postdoc}

On average, the respondents had been employed for 30 months as postdoc researchers at the time they completed the questionnaire. Postdocs with children had been working for a longer time on average as postdoctoral researchers (44 vs. 24 months; $p<0.001$ ). Generally, postdocs had been working for 20 months as a postdoc at their current university, which suggests that they are piling up postdoc positions in different locations. This is in line with the findings of Van Arensbergen et al. (2013) that postdocs are very mobile, as every year $40 \%$ transfer to a different position compared to only 10-15\% mobility among assistant and associate professors. Since only limited options are available for permanent positions at universities, the period between graduating and obtaining a permanent position in academia can be quite long (e.g., Nerad and Cerny 1999; Van Engen et al. 2010). However, the literature shows that academics, who have been working in a postdoc position for more than 5 years, are less likely to obtain a permanent or tenured position in academia (Nerad and Cerny 1999), as postdocs will grow older and become more specialized (Van Balen 2010). The work by Chlosta et al. (2010) reveals that, after a longer duration of their temporary contracts, postdocs in Germany are less likely to invest in a risky academic career. In the general university included in our sample, 21 postdocs $(15 \%)$ have held a postdoc position for more than 5 years compared to six postdocs $(6 \%)$ in the technical university. Nationality matters also, as postdocs with a Dutch nationality have been working much longer as postdoctoral researchers, on average, than their international counterparts in the same position (42 vs. 25 months; $p<0.001$ ).

\section{Preliminary career features}

We chose to investigate the preliminary career performance of postdocs on the basis of three indicators: Whether they obtained a personal research grant during their Ph.D. period, whether they had earned a Ph.D. with distinction, and whether they functioned within an established Ph.D. program. These are clearly observable factors and can potentially affect

\footnotetext{
${ }^{1}$ Researchers in the medical and health fields are not included in this study because research in this field is conducted in one of the eight academic medical centers.
} 
their further career options, in contrast to other postdocs. Other investigators used similar indicators (e.g., Fitzenberger and Schulze 2013), but we realize that these indicators cannot fully explain the quality of the postdocs' performance. Of the postdocs, $69 \%(n=156)$ obtained their Ph.D. through a Ph.D. program; about $25 \%(n=56)$ received a Ph.D. with distinction; and $31 \%(n=69)$ obtained a personal research grant during their Ph.D. period. More postdocs from the general university (36\%) received this award compared to their colleagues from the technical university (23\%). As shown in Table 3, the scholarly performance of postdocs with a non-Dutch nationality is much higher compared to postdocs with a Dutch background.

\section{Career prospects}

When asked about their career aspirations and expectations, most respondents (85\%, $n=193$ ) prefer to stay at a university or research institute after their postdoc position is finished. This figure is quite comparable to postdocs employed in the UK and Japan, where 78 and $75 \%$, respectively, aspire to stay in academia (CROS 2013; NISTEP 2008). In Germany, this percentage is lower; $68 \%$ of all postdocs prefer an academic job (Fitzenberger and Schulze 2013). However, the postdocs with academic career ambitions are dissatisfied with their opportunities to continue working in academia. This aligns with recent studies from other countries; for example, the British study by Felisberti and Sear (2014) indicates that $67 \%$ of postdocs thought their academic job prospects were poor. Our analyses show that the longer the postdoc trajectory lasted, the less satisfied the respondents were concerning their career prospects. Postdocs with children have an even more negative view (mean $=3.48$ on a 7 -point scale) of their possible academic futures compared to their childless colleagues (mean $=4.24 ; p<0.001$ ). The lack of available positions in academia and the uncertain working conditions are the two most important factors that determine their future career prospects within universities, and $92 \%$ of the respondents are negative about their chances of ever securing a permanent position in academia, varying from fair $(21.7 \%)$, to poor (44.2 \%), to very poor $(26.4 \%)$. In addition, these limited prospects lead to feelings of not being appreciated within academia in their current position, as illustrated by the following quote:

I think it is a shame and actually shocking to press as much expertise, competence and output as possible out of post-doctoral researchers and not even give them back in exchange a chance for a proper career and safety. When you are in your thirties, it is not weird, especially for a woman, to expect after such long studies and with such a great $\mathrm{CV}$, to get a permanent position as reward and acknowledgement for her competence. (female, France, 35 years old, two children)

Of the 225 postdocs, only six have been promised a tenure-track position after fulfilling their postdoc jobs in a satisfactory manner. The extremely limited career prospects created a lot of stress for postdocs. Although most aspire to an academic career, weak career prospects in academia along with the current intense pressure to perform, including achieving publication and securing grants, require postdocs to consider alternative careers in the non-profit sector (e.g., education, government) or the profit sector (e.g., industry). This is illustrated by the following two quotes:

Although I enjoy my job a lot and would very much like to continue to pursue a career in science, I often consider changing career paths because of these negative 
Table 3 Scholarly performance of postdoc researchers

\begin{tabular}{llll}
\hline & Dutch nationality & Non-Dutch nationality & Chi-square \\
\hline Educated in Ph.D. Program & $54 \%(n=42)$ & $78 \%(n=114)$ & $\chi^{2}=13.468 ; p<0.001$ \\
Ph.D. with distinction & $12 \%(n=9)$ & $32 \%(n=46)$ & $\chi^{2}=10.943 ; p=0.001$ \\
Personal grant during Ph.D. & $19 \%(n=15)$ & $37 \%(n=54)$ & $\chi^{2}=7.519 ; p=0.006$ \\
\hline
\end{tabular}

Table 4 Training of postdocs during the postdoc period

${ }^{\mathrm{a}} \mathrm{BKO}=$ University Teaching Qualification

\begin{tabular}{ll}
\hline & Percentage \\
\hline No training/courses & $44 \%(n=99)$ \\
Language course(s) & $32.4 \%(n=73)$ \\
Postdoc Career Development Initiative course(s) & $10.2 \%(n=23)$ \\
Personal development course(s) & $12.4 \%(n=28)$ \\
Verbal communication course(s) & $8.4 \%(n=19)$ \\
Written communication course(s) & $6.7 \%(n=15)$ \\
Entrepreneurship course(s) & $2.2 \%(n=5)$ \\
Project management course(s) & $2.7 \%(n=6)$ \\
Effectiveness & $2.2 \%(n=5)$ \\
Education-BKO trajectory & \\
\hline
\end{tabular}

aspects. I also feel that sometimes this has a negative influence on my ability to do my job. (female, the Netherlands, 35 years old, two children)

...It is, forgive me, a stupid strategy from the university, which keeps on losing every year competent and expert people who get tired of working in precarious conditions and therefore choose a career in industry. (female, France, 35 years old, two children)

\section{Career Preparations}

Given the current career uncertainties in academia, indicated also by the postdocs themselves and shown in the previous section, it is quite remarkable that almost half of them did not attend any training module or course during their postdoc period (see Table 4). About $29 \%$ of the respondents developed some transferable skills such as linguistic, communicative, or management skills. Language courses were followed by the employment of almost one-third of the postdocs, particularly the non-Dutch-speaking postdocs, at both universities. Only $10 \%$ of our respondents attended a PCDI course ${ }^{2}$ such as Postdoc Retreat, Talent Cafe, or Postdoc-PI dialogues during their postdoc years. The initiative aims to be a mediator between Ph.Ds and academia, industry, public-private partnerships, and others (PCDI 2012).

A small number of postdocs spent time during their postdoc positions to further develop additional skills in order to expand their eligibility for career options beyond research. The

\footnotetext{
${ }^{2}$ In order to support young scientists in both academic and alternative career orientation, the Postdoc Career Development Initiative was established in the Netherlands in 2008. Until now, the scope of this initiative is rather limited as they only focus on the postdocs in the life sciences (PCDI 2012).
} 
postdocs are aware that networks are critical in preparation for the labor market; more than half who responded are actively networking in and outside the university. Only $7 \%$ (mainly those with a Dutch background) have developed some degree of research management experience, such as being a member of a research council or board.

\section{Working environments of postdocs}

\section{Daily environment}

Overall, postdoctoral researchers from both universities are quite satisfied with their daily working environments in the research group at which they are employed. On a 7-point scale, "direct contact with colleagues" received an average score of 5.73 (see Table 5). We also explored the extent to which postdocs are being supervised. In our data set, $79 \%$ of the postdocs had a supervisor. Overall, postdocs are satisfied with their supervision (average 5.55); they meet with their supervisor frequently and receive sufficient support and guidance. However, $20 \%$ of the respondents have no direct supervisor at all.

\section{The university as a working context}

As shown in Table 5, when all variables/items are considered, postdocs give the lowest (neutral) scores to the career guidance that they received from their university. As shown by the various quotes, postdocs complain about the lack of clarity regarding career prospects related to the somewhat undeveloped HRM and talent policies in this area. In addition, postdocs experience only limited recognition and support from their university

It feels like postdocs as a group of employees are overlooked... They do not have the same status as permanent employees, but they also do not have the resources to develop themselves like Ph.Ds have. (female, the Netherlands, 34 years old, two children)

... And yet, the training does not put any emphasis on alternate career paths or transferable skills. (female, US, 35 years old, no children)

In HRM policies, little attention is paid to the further career prospects of postdocs (in contrast to Ph.D. students).

There should be more programs or workshops directed to postdocs at the universities. Now the majority of them are connected to PhD students only. (female, Spain, 37 years old, no children)

The university does not devote any time to career policy. They are not concerned with the question of (future) demand for academic positions and the number of scholars they should train to fill these (future) positions. It is difficult to imagine any other public or private sector that just keeps investing in training young employees, even when (future) demand for trained professionals stagnates or even declines. (male, the Netherlands, 38 years old, no children)

Nationality makes a difference, as postdocs with a Dutch background are significantly less satisfied with both employment conditions and career guidance of the university compared to their international colleagues. 
Table 5 Satisfaction of postdoc researchers (7-point scale; $1=$ very dissatisfied; $7=$ very satisfied)

\begin{tabular}{lllllll}
\hline & $N$ & Mean & Median & SD & Min & Max \\
\hline Contact with colleagues & 220 & 5.73 & 6.00 & 1.185 & 1 & 7 \\
Life in general & 220 & 5.64 & 6.00 & 1.108 & 1 & 7 \\
Guidance from immediate supervisor & 220 & 5.55 & 6.00 & 1.503 & 1 & 7 \\
Selecting a career in academia & 220 & 5.35 & 6.00 & 1.474 & 1 & 7 \\
Current employment conditions & 220 & 5.14 & 6.00 & 1.486 & 1 & 7 \\
Work-life balance & 220 & 4.93 & 5.00 & 1.494 & 1 & 7 \\
Selecting postdoc positions as a career step & 220 & 4.92 & 5.00 & 1.450 & 1 & 7 \\
Guidance from the university & 220 & 4.48 & 4 & 1.497 & 1 & 7 \\
\hline
\end{tabular}

\section{Work-life balance}

Postdocs are satisfied with their lives in general (average score 5.64; see Table 5), although the combination of work and private life is still challenging for them. The open questions in the survey suggest that the relatively weak career prospects in academia negatively impact the struggle for work-life balance among postdoc researchers. This is illustrated by the following three quotes:

I have found a good way of combining academic life and private life, but I am still worried about my future since this position will not lead to a permanent job. (female, Spain, 37 years old, no children)

I love doing research and, as a postdoc, I have quite a lot of time for that. However, now that my children are reaching school age, the uncertain career prospects are starting to weigh heavily as a disadvantage, in particular because my husband is a postdoc, too. (female, the Netherlands, 37 years old, two children)

It takes far too long to obtain a certain amount of certainty job-wise, especially for those with children. It is not nice to not know where you will have to live or still move to in the coming years whilst your children are going to school, starting sports, etc. The lack of permanent jobs is one thing. But on top of that, the certainty of having to leave the place where you currently are after a postdoc is even worse! That makes it very hard to build a life and provide for stability for the family. (female, the Netherlands, 39 years old, two children)

\section{Career prospects in academia}

In this final section, we investigated how the satisfaction of postdocs with regard to career prospects in academia is associated with multiple predictors, such as personal characteristics, research field, career features, and trajectories of the respondents. Therefore, we conducted a multiple regression analysis. As shown in Table 6, perceptions about the academic career prospects of postdocs are associated with the research field in which they are working. Postdocs in the humanities and the social and behavioral sciences have more negative opinions about academic career prospects compared to postdocs employed in the 
faculty of sciences. In regard to personal factors, nationality plays a role as well. Postdocs with an international, non-Dutch background are more positive about their career prospects in academia. Interestingly, gender, as well as family-related circumstances, has no independent effect on the career prospects of postdoctoral researchers. Finally, the length of the postdoc period is associated with academic career prospects; the longer the postdocs have been working at a postdoc position, the lower their career prospects within academia. The past performances of the postdocs do not have an independent effect.

\section{Conclusions and discussion}

Our study provides a rare glimpse into an increasingly important group of researchers. Postdocs seem to be trapped between their own academic ambitions and the lack of available options to continue their careers at the university. Most important, the findings from our studies indicate that the postdoc population is substantial and growing; the duration of their postdoc employment is approaching the length of the Ph.D. trajectory (=48 months), while the length of their postdoc employment negatively affects their career satisfaction and prospects. Postdocs are determined to remain in academia and are quite satisfied with their work environment despite their restricted prospects. However, their preparations for a non-academic career path are quite limited, and this coincides with the limited availability of any policies or coaching provided by their universities. Overall, our survey study shows few gender differences. Nationality does matter, as we show that nonDutch postdocs (1) have a better scholarly performance during the Ph.D. period and (2) are

Table 6 Regression equations for satisfaction of postdocs with their career prospects within academia
$*$, **, and *** denote statistically significant difference of the independent variable at the 5, 1, and $0.1 \%$ levels, respectively

\begin{tabular}{|c|c|c|c|}
\hline \multirow[t]{2}{*}{ Variables } & \multicolumn{3}{|l|}{ Model } \\
\hline & $\mathrm{B}$ & Std. error & $p$ value \\
\hline \multicolumn{4}{|c|}{ Field (ref. is natural sciences) } \\
\hline Archeology & -.172 & .450 & .703 \\
\hline Humanities & -.848 & .363 & $.021 *$ \\
\hline Social sciences & -1.216 & .410 & $.003 * *$ \\
\hline Engineering & -.147 & .269 & .585 \\
\hline \multicolumn{4}{|l|}{ Personal characteristics } \\
\hline Female & -.236 & .225 & .296 \\
\hline No children & .130 & .242 & .591 \\
\hline Dutch nationality & -.808 & .255 & $.002 * *$ \\
\hline \multicolumn{4}{|l|}{ Career features } \\
\hline Having a supervisor & -.435 & .267 & .105 \\
\hline Length of postdoc period & -.016 & .004 & $.000 * * *$ \\
\hline Ph.D. program & .372 & .245 & .131 \\
\hline Ph.D. with distinction & .013 & .258 & .960 \\
\hline Personal grant & .362 & .243 & .137 \\
\hline Constant & 4.984 & & \\
\hline $\mathrm{F}$ & 6.611 & & \\
\hline $\mathrm{R}$ square & .281 & & \\
\hline Valid cases & 216 & & \\
\hline
\end{tabular}


more satisfied with both employment conditions and career guidance of the university compared to their Dutch postdoc counterparts. It is interesting to see that discipline plays a role, as postdocs in the social sciences and humanities are clearly less satisfied than their counterparts in the hard sciences.

Our analyses lead to several policy recommendations, as we have demonstrated that it is urgent for universities to regard postdoctoral researchers much more seriously within their current labor organization. A simple starting point will be more visibility through the recognition of postdocs as a separate staff category. Second, universities should encourage their support toward postdocs by developing appropriate and focused HRM policies. Postdoc talent management should include, e.g., career guidance tailored to postdocs with training modules concerning personal and professional development both within and beyond their academic fields and establishing a network and contacts in the labor market. Differences among the various disciplines, particularly the social sciences and humanities, should be taken into account (Bäker 2015). The launching of a postdoc community will improve the visibility of postdocs and enhance their position at the strategic level (e.g., the university board). An example of a promising practice is that of Ghent University in Belgium, which recently launched a strategic plan for their postdocs (https://www.ugent. be/en/ghentuniv/strategic-plan/postdoc-community/postdoctalent.htm).

The work by Davis (2009) has already shown that relatively small measures such as setting up a research plan and formal reviews can have significant effects. Finally, every postdoc should have a mentor or a coach, as the literature has demonstrated that guidance and mentorship are important for career development of academics (e.g., Fitzenberger and Schulze 2013; Mellors-Bourne and Metcalfe 2009; Van Balen et al. 2012; Van der Weijden et al. 2015). Not only university policy makers but also top and middle management should be involved in this process.

Several studies (e.g., Fruytier and Brok 2007; Freese et al. 2013) reveal that the lack of commitment and active involvement of members of the executive board, deans, and directors of research institutes are obstacles in the development and implementation of HRM policies. These studies, including ours, show that postdocs are negative about their future prospects in academia. However, as explained above, postdocs rarely attempt to pursue alternative career paths, e.g., by attending courses outside their research areas, and spend very little time pursuing their own personal development. The attitudes of postdocs and their supervisors toward their professional and career development require change (Science Careers 2012); part of this change involves the postdocs themselves, and part of it comes down to the relationship with their supervisors, in most cases full professors. Several studies have indicated that they are the most powerful actors in Dutch academia (Meijer 2002), as they function as intermediaries (Fruytier and Timmerhuis 1995) and gatekeepers (Van Balen 2010; Van den Brink 2009) between the university and the individual professionals under their supervision. They have an important say in further career building and in determining whether or not a prospective academic is admitted to the scientific community. In conclusion, our study suggests that it is not sufficient to focus strictly on the development of postdoc career policies; consideration should include the interests and needs of postdocs themselves and other actors involved in their direct and indirect work environment (Thunnissen 2015).

Acknowledgments The authors wish to thank the Human Resource Management departments of both universities for their support and collaboration in this study. 
Open Access This article is distributed under the terms of the Creative Commons Attribution 4.0 International License (http://creativecommons.org/licenses/by/4.0/), which permits unrestricted use, distribution, and reproduction in any medium, provided you give appropriate credit to the original author(s) and the source, provide a link to the Creative Commons license, and indicate if changes were made.

\section{References}

Bäker, A. (2015). Non-tenured post-doctoral researchers' job mobility and research output: An analysis of the role of research discipline, department size, and co-authors. Research Policy, 44(3), 634-650.

Bessudnov, A., Guardiancich, I., \& Marimon, R. (2014). A statistical evaluation of the effects of a structured postdoctoral programme. Studies in Higher Education,. doi:10.1080/03075079.2014.899340.

Bulmahn, E. (2001). Leistungsorientierte Entlohnung - kann die geplante Dienstrechtsreform die Abwanderung von qualifizierten Nachwuchswissenschaftlern verhindern. Ifo Schnelldienst 8, Jhg. 54, 5-7.

Cantwell, B., \& Taylor, B. J. (2013). Internationalization of the postdoctorate in the United States: Analyzing the demand for international postdoc labor. Higher Education, 66(5), 551-557. doi:10.1007/ s10734-013-9621-0.

Chlosta, K., Pull, K., Fiedler, M., \& Welpe, I. (2010). Should I stay or should I go? Waum machwuchswissenschaftler in der Betriebswirtschafslehre das Universitassystem verlassen. Zeitschrift fur Betriebswirtschaft, 80(11), 1207-1229.

CROS (2013). Careers in research online survey. https://www.vitae.ac.uk/vitae-publications/reports/crosreport-vitae-2013.pdf/view. Retrieved January 28, 2015.

Davis, G. (2009). Improving the postdoctoral experience: An empirical approach. In R. B. Freeman \& D. L. Goroff (Eds.), Science and engineering careers in the United States: An analysis of markets and employment. Chicago: University of Chicago Press.

De Goede, M., Belder, R., \& De Jonge, J. (2013). Academic Careers in the Netherlands, Facts \& Figures. www.rathenau.nl. Retrieved November 7, 2013.

De Grande, H., De Boyser, K. \& Van Rossem, R. (2010). Carrièrepaden van doctoraatshouders in België: Loopbaanpatronen naar wetenschapsgebied. HR2 e-document (Nr.1), Universiteit Gent, https://www. ugent.be/ps/sociologie/nl/onderzoek/cst/papers/publicseries/hr2edocs.

Editorial. (2004). Wanted: Career path for postdocs. Nature Materials,. doi:10.1038/nmat 1055.

Enders, J., DeBoer, H., \& Westerheijden, D. F. (Eds.). (2011). Reform of higher education in Europe. Rotterdam/Boston/Taipei: Sense Publishers.

Felisberti, F. M., \& Sear, R. (2014). Postdoctoral researchers in the UK: A snapshot at factors affecting their research output. PLoS One 9(4), e93890. doi:10.1371/journal.pone.0093890.

Fitzenberger, B., \& Schulze, U. (2013). Up or out: Research incentives and career prospects of postdocs in Germany. German Economic Review, 15(2), 287-328.

Freese, C., Evers, G., Van den Berg, P., Arends, P., \& Sens, T. (2013). Strategische personeelsplanning bij de universiteiten. The Hague: SoFoKles.

Freijsen, R., Van Arensbergen, P., \& Van der Weijden, I. (2011). Wetenschappelijk Loopbaanbeleid: Kansen en Knelpunten. Loopbaanvisie, 4, 86-90.

Fruytier, B., \& Brok, B. (2007). Tenure track een goed instrument voor talentmanagement? Inventarisatie van risico's en kansen van tenure track voor de werving, binding en loopbaanbegeleiding van wetenschappelijk talent op Nederlandse universiteiten. The Hague: SoFoKles.

Fruytier, B., \& Timmerhuis, V. (1995). Mensen in onderzoek; het mobiliseren van human resources in wetenschapsorganisaties. Van Gorcum: Assen.

Gemme, B., \& Gingras, Y. (2012). Academic careers for graduate students: a strong attractor in a changed environment, Higher Education, 63(6), 667-683. http://sciencecareers.sciencemag.org/career_ magazine/previous_issues/articles/2013_09_12/caredit.a1300197. Retrieved 28 Jan 2015.

Häyrinen-Alestalo, M., \& Peltola, U. (2006). The problem of a market-oriented university. Higher Education, 52, 251-281.

Horta, H. (2009). Holding a post-doctoral position before becoming a faculty member: Does it bring benefits for the scholarly enterprise? Higher Education, 58, 689-721.

Kwiek, M., \& Antonowicz, D. (2015). The changing paths in Academic Careers in European Universities: Minor steps and major milestones. In T. Fumasoli, G. Goastellec, \& B. M. Kehm (Eds.) Academic 
Work and Careers in Europe: Trends, Challenges, Perspectives. The Changing Academy-The Changing Academic Profession in International Comparative Perspective, 12, 41-68.

Leonard, D., Becker, S., \& Coate, K. (2004). Continuing professional and career development: The doctoral experience of education alumni at a UK university. Studies in Continuing Education, 26(3), 369-385.

McAlpine, L. (2012). Academic work and careers: Relocation, relocation, relocation. Higher Education Quarterly, 66(2), 174-188.

McAlpine, L., \& Emmioğlu, E. (2014). Navigating careers: Perceptions of sciences doctoral students, postPh.D. researchers and pre-tenure academics. Studies in Higher Education, doi:10.080/03075079.2014. 914908.

Meijer, M. (2002). Behoud Talent! Een rapportage over de verschillende aspecten die een rol spelen bij de begeleiding van promovendi.

Mellors-Bourne, R., \& Metcalfe, J. (2009). Careers in research online survey (CROS) 2009: Analysis of aggregated UK results. Cambridge: Careers Research and Advisory Centre (CRAC).

Mitchell, J. S., Walker, V. E., Annan, R. B., Corkery, T. C., Goel, N., Harvey, L., et al. (2013). The 2013 Canadian Postdoc Survey: Painting a Picture of Canadian Postdoctoral Scholars. Canada: Canadian Association of Postdoctoral Scholars and Mitacs.

National Institute of Science and Technology Policy (NISTEP). (2008). Investigative survey on research activities and awareness of postdoctoral fellows: Analysis on career choices of postdoctoral scholars. http://www.nistep.go.jp/achiev/abs/eng/mat161e/pdf/mat161ae.pdf. Retrieved April 3, 2014.

National Institute of Science and Technology Policy (NISTEP). (2009). Survey on research activities and attitudes of postdoctoral fellows. http://www.nistep.go.jp/achiev/abs/eng/mat159e/pdf/mat159ae.pdf. Retrieved April 3, 2014.

Nerad, M., \& Cerny, J. (1999). Postdoctoral patterns, career advancement, and problems. Science, 285, $1533-1535$.

O'Grady, T., \& Beam, P. S. (2011). Postdoctoral scholars: A forgotten library constituency? Science \& Technology Libraries, 30(1), 76-79.

PCDI. (2012). Your Ph.D. as a stepping stone to success. BCF guide. http://www.pcdi.nl/images/stories/pdf/ PCDI_artikel_in_BCF_Guide_2012.pdf.

Prpic, K., van der Weijden, I., \& Asheulova, N. (2014). (Re)searching academic careers. Institute for the History of Sciences and Technology, St. Petersburg. Russian Academy of Sciences, Publishing House Nestor-Historica, Sociology of Science and Technology Network of the European Sociological Association. St. Petersburg, Russia.

Reja, U., Lozar Manfreda, K., Hlebec, V. \& Vehovar, V. (2003). Open-ended vs. close-ended questions in web questionnaires. In: A. Ferligoj \& A. Mrvar (Eds.) Developments in Applied Statistics. Metodološki zvezki, 19, Ljubljana: FDV.

Scaffidi, A. K., \& Berman, J. E. (2011). A positive postdoctoral experience is related to quality supervision and career mentoring, collaborations, networking and a nurturing research environment. Higher Education, 62(6), 685-698.

Schomburg, H. (2007). The professional success of higher education graduates. European Journal of Education, 42(1), 35-57. doi:10.1111/j.1465-3435.2007.00286.x.

Stanford, M., McKee, T., Crawley, A., Frasch, M., Mooibroek, M., Chambenoit, O., \& Roderick, C. (2009). A postdoctoral crisis in Canada: From the "ivory tower" to the academic "parking lot". Canada: Canadian Association of Postdoctoral Scholars.

Teelken, C. (2015). Hybridity, coping mechanisms, and academic performance management: Comparing three countries. Public Administration, 93(2), 307-323.

Thunnissen, M. (2015). Talent management in academia: An exploratory study in Dutch universities using a multidimensional approach. Dissertation. ISBN 978-90-393-6268-6.

Thunnissen, M., Boselie, P., \& Fruytier, B. (2013). Talent management and the relevance of context: Towards a pluralistic approach. Human Resource Management Review,. doi:10.1016/j.hrmr.2013.05. 004.

Thunnissen, M., \& Fruytier, B. (2014). Het Mobiliseren van Human Capital: een overzicht van 25 jaar HRM-beleid op Nederlandse universiteiten. Tijdschrift voor HRM, 1, 1-24.

Van Arensbergen, P., Hessels, L. \& van der Meulen, B. (2013). Talent Centraal. Ontwikkeling en selectie van wetenschappers in Nederland. Rathenau Instituut. SciSa 1330, The Hague.

Van Balen, B. (2010). Op het juiste moment op de juiste plaats. Waarom wetenschappelijk talent een wetenschappelijke carrière volgt. The Hague: Rathenau instituut.

Van Balen, B., Van Arensbergen, P., Van der Weijden, I., \& Van den Besselaar, P. (2012). Determinants of success in academic careers. Higher Education Policy, 25(3), 313-334.

Van den Brink, M. (2009). Behind the scenes of science: Gender practices in the recruitment and selection of professors in the Netherlands. Nijmegen: Radboud University Nijmegen: Dissertation. 
Van den Brink, M., Fruytier, B., \& Thunnissen, M. (2013). Talent management in academia: Performance systems and HRM policies. Human Resource Management Journal, 23(2), 180-195.

Van der Weijden, I., Belder, R., Van Arensbergen, P., \& Van den Besselaar, P. (2015). How do young tenured professors benefit from a mentor? Effects on management, motivation and performance. Higher Education, 69(2), 275-287. doi:10.1007/s10734-014-9774-5.

Van Engen, M., Bleijenbergh, I., \& Vinkenburg, C. (2010). Onderzoeksproject Talent naar de Top Technische Universiteit Delft: Structurele en culturele belemmeringen in de doorstroom van vrouwen naar hogere functies binnen de TU Delft. https://intranet.tudelft.nl/fileadmin/UD/MenC/Support/Internet/ TU_Website/TU_Delft_Medewerkers/Loopbaan_en_ontwikkeling/Diversiteit/doc/Onderzoeksrapport_ TU_Delft_2010.pdf. Retrieved 27 January 2015.

Zomer, A., \& Benneworth, P. (2011). The rise of the university's third mission. In J. Enders, H. F. de Boer, \& D. F. Westerheijden (Eds.), Reform of higher education in Europe (pp. 81-101). Rotterdam, Netherlands: Sense Publishers. 